Dept. of Bacteriology,

Animal Health Research Institute,

Mansoura Laboratory.

\title{
STUDY ON BACTERIAL CAUSES OF DIARRHOEA IN NEO-NATE CALVES IN DAKAHLIA PROVINCE
}

(With 4 Tables)

\author{
By \\ A.H. MOUSTAFA; M. EL-SAYED HATAB \\ and M.M. ABD-EL-LATIF \\ (Received at 31/5/2007)
}

دراسة عن الأسباب البكتيرية للإسهال فى العجول حيثة الولادة

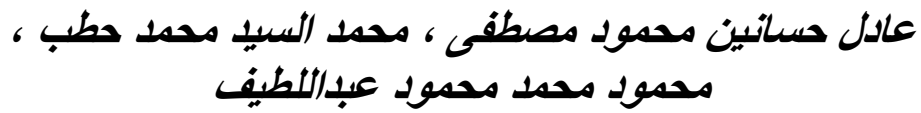

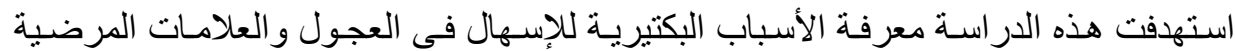

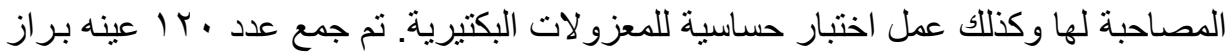

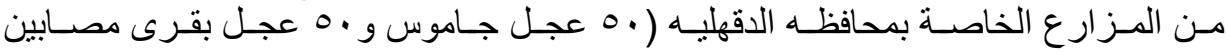

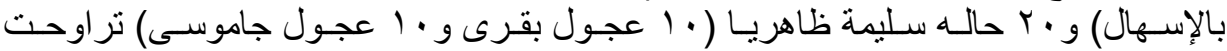

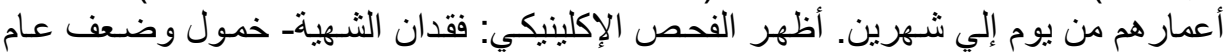

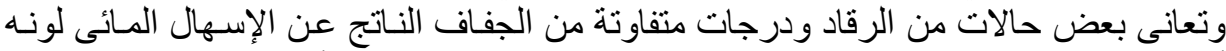

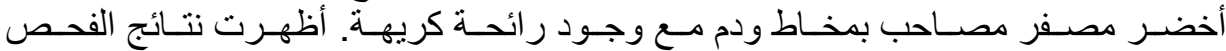

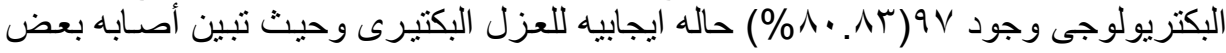

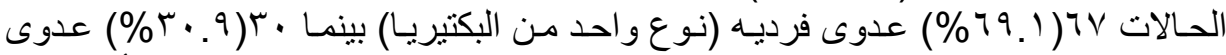

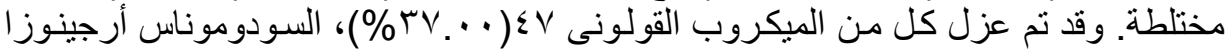

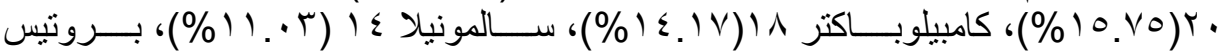

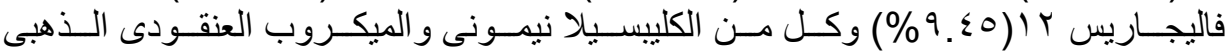

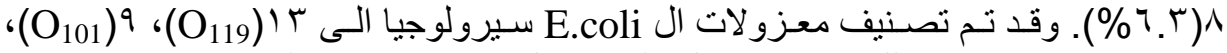

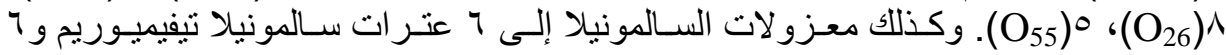

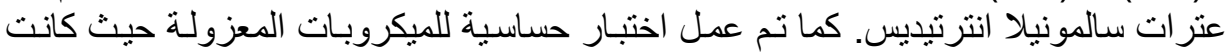

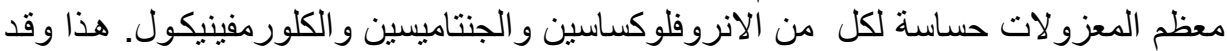

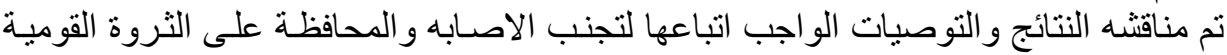
وصحة الإنسان.

\section{SUMMARY}

The present study was aimed to investigate the bacterial causes of diarrhoea in calves with symptoms and sensitivity test for isolated 
bacteria. 120 feacal samples (50 diarrhoeic cows \& buffaloe calves and 10 each of apparently health cows and buffaloe calves) their age ranged from birth up to 2 month old. The clinical symptoms of diarrhoeic calves were depression, weekness, partiel loss of appetite, some cases suffered from recumbeny and varing degrees of dehyderation, diarrhoea accompained with mucous or and blood with offensive odour. The bacteriological examination revealed $67(69.1 \%)$ and $30(30.9 \%)$ were single and mixed infection respectively. E.coli was isolated at incidence percentage 47(37\%), Pseudomonas aeruginosa 20(15.75), Campylobacter 18(14.17\%), Salmonella 14(11.03\%), Proteus vulgaris $12(9.45 \%)$ and each of Klebsiella pneumoniae and Staphylococcus aureus $8(6.3 \%)$. E.coli isolates were identified serologically into $13\left(\mathrm{O}_{119}\right), 9\left(\mathrm{O}_{101}\right), 8\left(\mathrm{O}_{26}\right)$ and $5\left(\mathrm{O}_{55}\right)$. Also Salmonella spp. was identified as 6 Salmonella typhimurium and 6 Salmonella enteritidis. In vitro sensitivity pattern of isolated strains proved that Enrofloxacin and Gentamycin and Chloramphenicol were the most effective drugs for most isolates.

Key words: Diarrhoea, neo-nate calves, E.coli, Salmonella, antibiotic sensitivity

\section{INTRODUCTION}

Diarrhoea is considered to represent a problem that may lead to great economical losses, as it consider the most important cause of calf morbidity and mortality especially among newly born buffalo and cow calves in Egypt and allover the world (Bayomi, et al., 1996). It is caused by a combination of many risk factors. Interaction between environments, nutritional imbalance, improper colostrum intake and virulence of pathogens provoke the imbalance of intestinal equilibrium resulting in diarrhoea (Radostits, et al., 1994). Several bacterial species may be involved in diarrhoea and losses of calves, the most important being is certain strains of E.coli that possessing virulent factors, Salmonella species, Campylobacter species, Proteus, Klebsiella. These pathogens are responsible for great mortality and various morbidity changes and at the same time constitute a hazard to public health. (El-hamamy, et al., 1999; Sadiek \& Hussein, 1999; Novert \& Hammad, 2001 and Harbby, 2002).

Several outbreaks and sporadic cases of diarrhoea were occured in neonatal calves especially in intensive farm production and larg flocks in our area at El-Dakahlia Governorate. Therefore, the present work was 
aimed to study the role of bacteria as a causative agent of diarrhoea in calves, also determine in vitro-the antibiotic sensitivity of isolated organisms.

\section{MATERIALS and METHODS}

\section{1- Samples:}

A total of one hundred and twenty rectal faecal samples were collected from (50 each of diarrhoeic buffaloe \& cattle calves and 10 each of apparently healthy buffaloe and cow calves) all aging from birth up to 2 month old. Samples were obtained by means of sterile probes introduced into the rectum of each calf, kept in sterile plastic bottle. All samples were labeled, kept in ice box and sent to the laboratory as quickly as possible for bacteriological examination. The samples were collected from private farm at El-Dakahlia Province.

\section{2- Media:}

- Rappaporte-Vasiliadis broth (R.V., Oxoid, CM 669), Trypticase soya broth

- Blood agar; MacConky's agar (Oxoid, CM 7); Eosin methylene blue agar (EMB, Oxoid, CM 69); Xylose lysine deoxycholate agar (XLD, Oxoid, CM469) and Campylobacter agar base (Oxoid, CM689).

\section{3- Methods:}

Each faecal sample was divided into 3 portions under aseptic condition. The first part was streaked directly onto predried surface of Blood agar; MacConky's agar; Eosin methylene blue agar; Xylose lysine deoxycholate agar. The plates were incubated aerobically at $37^{0} \mathrm{C}$ for 24 hours. The second faecal part was inculated into RappaporteVasiliadis broth and incubated at $43^{\circ} \mathrm{C} / 24$ hours, loopfules from incubated R.V. broth were streaked onto XLD agar plate with incubation at $37^{0} \mathrm{C}$ for 24 hours.

The growing colonies on various plates were examined morphologically, culturally and biochemically according to Edwards and Ewing, (1972); Cruickshank, et al. (1982); Finegold and Baron, (1986); Collins, et al. (1995) and Quinn, et al. (2002).

The third portion of each faecal sample was used for isolation of Campylobacter species. One gram of faecal material was triturated in one $\mathrm{ml}$ of sterile saline solution $(0.9 \%)$ and then centrifuged at 3000 r.p.m. for 5 minutes. Few drops of the supernatant fluid were immediately cultivated onto Campylobacter agar base, in which 7\% defibrinated horse blood and Skirrow supplement was added. The inoculated plates were incubated under microairophilic condition 
$\left(5 \% \mathrm{O}_{2}, 10 \% \mathrm{Co}_{2}\right.$ and $\left.85 \% \mathrm{~N}_{2}\right)$ in an anaerobic jar at $25{ }^{\circ} \mathrm{C}, 37{ }^{\circ} \mathrm{C}$ and $42^{\circ} \mathrm{C}$ for 72 hours ( Skirrow and Benjamin, 1980). The suspected typical growing colonies were identified morphologically, culturally and biochemically according to Perscott and Munroe (1982).

- The identified E.coli strains were tested for enterotoxin production through growing the E.coli isolate in trypticase soya broth at $37{ }^{\circ} \mathrm{C}$ in stationary culture overneight, culture were centrifuged at 4000 r.p.m. for 20 minutes. The supernatant was tested using commercially VET-RPLA kits (reversed passive Latex agglutination, Oxoid, TD 0920A) following the manufacturer's direction \& Scotland, et al. (1989).

\section{4- Serological identification of:}

\section{a) E.coli:}

Serological identification of purified E.Coli strains using available agglutinating Coli test sera (Behring werk, AG Marburg) was done according to manufacturer's instruction. (Labn, Germany).

\section{b) Salmonella:}

The biochemically identified Salmonella strains were subjected for serological identification as described by Edwards and Ewing, (1972); Kaufmann, (1973) and the instruction of the manufacturer (Denken Selken Co. LTD, Tokyo, Japan).

\section{5- In vitro antibiotic sensitivity test:}

The disc diffusion technique was performed on the isolated bacteria using Muller-Hinton media (Oxoid). Ten chemotherapeutic disks kindly supplied by Oxoid and namely Ampicillin, Amoxycillin, Chloramphenicol, Enrofloxacin, Erythromycin, Gentamycin, Streptomycin, Penicillin, Oxytetracycline and Trimethoprimsulphamethoxazole were used. The degree of sensitivity was interpreted according to Koneman, et al. (1994), Quinn, et al. (1994) and Oxoid Manual, (1998).

\section{RESULTS}

\section{A-Clinical signs:}

The main clinical signs encountered of diarrhoeic calves were partiel loss of appetite,depression, straining, tenesmus, dehyderation and some cases were recumbent. Feces were watery, greenish, yellow accompained with mucoid and /or blood discharg with offensive odour.

\section{B- Results of bacteriological examination of calves:}

Were illustrated in Table 1, 2, 3 and 4. 
Table 1: Results of bacteriological examination of calves.

\begin{tabular}{|c|c|c|c|c|c|c|c|c|}
\hline \multirow{3}{*}{ Cases } & \multirow{3}{*}{$\begin{array}{l}\text { Total No. } \\
\text { of } \\
\text { examined } \\
\text { samples }\end{array}$} & \multirow{2}{*}{\multicolumn{2}{|c|}{$\begin{array}{l}\text { Positive } \\
\text { samples }\end{array}$}} & \multicolumn{4}{|c|}{$\begin{array}{c}\text { Prevalence of single \& mixed } \\
\text { culture }\end{array}$} & \multirow{3}{*}{$\begin{array}{c}\text { Total No. } \\
\text { of } \\
\text { isolates }\end{array}$} \\
\hline & & & & \multicolumn{2}{|c|}{ Single isolate } & \multicolumn{2}{|c|}{ Mixed isolate } & \\
\hline & & No. & $\%$ & No. & $\%$ & No. & $\%$ & \\
\hline 1-Diarrhoeic calves: & & & & & & & & \\
\hline a-Buffaloe calves & 50 & 41 & 82 & 24 & 58.54 & 17 & 41.46 & 58 \\
\hline b-Cows calves & 50 & 43 & 86 & 30 & 69.77 & 13 & 30.23 & 56 \\
\hline 2-Apprently healthy & & & & & & & & \\
\hline a-Buffaloe calves & 10 & 6 & 60 & 6 & 100.0 & -- & -- & 6 \\
\hline b-Cows calves & 10 & 7 & 70 & 7 & 100.0 & -- & -- & 7 \\
\hline Total & 120 & 97 & 80.83 & 67 & 69.1 & 30 & 30.9 & 127 \\
\hline
\end{tabular}

Table 2: Incidence of bacteria isolated from the examined calves.

\begin{tabular}{|c|c|c|c|c|c|c|c|c|c|c|}
\hline \multirow{4}{*}{ Bacterial isolates } & \multicolumn{8}{|c|}{ Condition of calves } & \multirow{3}{*}{\multicolumn{2}{|c|}{ Total }} \\
\hline & \multicolumn{4}{|c|}{ Diarrhoeic calves } & \multicolumn{4}{|c|}{ Apparently healthy } & & \\
\hline & \multicolumn{2}{|c|}{$\begin{array}{c}\text { Buffaloe } \\
(* 50)\end{array}$} & \multicolumn{2}{|c|}{$\begin{array}{l}\text { Cows } \\
(* 50)\end{array}$} & \multicolumn{2}{|c|}{$\begin{array}{c}\text { Buffaloe } \\
(* 10)\end{array}$} & \multicolumn{2}{|c|}{$\begin{array}{l}\text { Cows } \\
(* 10)\end{array}$} & & \\
\hline & No. & $\%$ & No. & $\%$ & No. & $\%$ & No. & $\%$ & No. & $\%$ \\
\hline E. coli & 25 & 50.00 & 22 & 44.00 & - & - & - & - & 47 & 37.00 \\
\hline Salmonella spp. & 8 & 16.00 & 6 & 12.00 & - & - & - & - & 14 & 11.03 \\
\hline Ps. aeruginosa & 10 & 20.00 & 10 & 20.00 & - & - & - & - & 20 & 15.75 \\
\hline Campylobacter spp. & 8 & 16.00 & 10 & 20.00 & - & - & - & - & 18 & 14.17 \\
\hline Proteus vulgaris & 3 & 6.00 & 4 & 8.00 & 2 & 33.33 & 3 & 42.86 & 12 & 9.45 \\
\hline Klebsiella pneumoniae & 2 & 4.00 & 2 & 4.00 & 2 & 33.33 & 2 & 28.57 & 8 & 6.30 \\
\hline Staph. aureus & 2 & 4.00 & 2 & 4.00 & 2 & 33.33 & 2 & 28.57 & 8 & 6.30 \\
\hline Total & 58 & & 56 & & 6 & & & & 127 & 100.00 \\
\hline
\end{tabular}

* The number of examined calves

* The percentage was calculated according to total isolates (127)

Table 3: Serological identification of isolated E. coli and Salmonella strains.

\begin{tabular}{|c|c|c|c|c|c|c|c|c|c|c|c|c|c|c|c|c|c|c|}
\hline \multirow{3}{*}{$\begin{array}{c}\text { Source of } \\
\text { Samples } \\
\text { Diarrhoeic }\end{array}$} & \multicolumn{10}{|c|}{ *E. coli } & \multirow{3}{*}{ 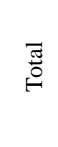 } & \multicolumn{6}{|c|}{ Salmonella } & \multirow{3}{*}{$\stackrel{\pi}{0}$} \\
\hline & \multicolumn{2}{|c|}{$\mathrm{O}_{119}$} & \multicolumn{2}{|c|}{$\mathrm{O}_{101}$} & \multicolumn{2}{|r|}{$\mathrm{O}_{26}$} & \multicolumn{2}{|c|}{$\mathrm{O}_{55}$} & \multicolumn{2}{|c|}{ Untype } & & \multicolumn{2}{|c|}{ S.typhimurium } & \multicolumn{2}{|c|}{ S.enteritidis } & \multicolumn{2}{|c|}{ Untype } & \\
\hline & No. & $\%$ & No. & $\%$ & No. & $\%$ & No. & $\%$ & No. & $\%$ & & No. & $\%$ & No. & $\%$ & No. & $\%$ & \\
\hline $\begin{array}{c}\text { a-buffaloe } \\
\text { Calves }\end{array}$ & 7 & 28.0 & 2 & 8.0 & 5 & 20.0 & 3 & 12.0 & 8 & 32.0 & 25 & 3 & 37.50 & 3 & 37.50 & 2 & 25.0 & 8 \\
\hline $\begin{array}{l}\text { b- cows } \\
\text { calves }\end{array}$ & 6 & 27.27 & 7 & 31.82 & 3 & 13.64 & 2 & 9.0 & 4 & 18.18 & 22 & 3 & 50.0 & 3 & 50.0 & - & - & 6 \\
\hline Total & 13 & & 9 & & 5 & & 12 & & & & 47 & 6 & & 6 & & 2 & & 14 \\
\hline
\end{tabular}

*All were produce LT toxin. 
Table 4: In vitro sensitivity test for the isolates recovered from diarrhoeic calves

\begin{tabular}{|c|c|c|c|c|c|c|}
\hline \multicolumn{2}{|c|}{$\begin{array}{c}\text { Antibiotic } \\
\text { disc }\end{array}$} & E.coli & Salmonella & $\begin{array}{c}\text { Ps. } \\
\text { aeruginosa }\end{array}$ & $\begin{array}{l}\text { Staph. } \\
\text { aureus }\end{array}$ & $\begin{array}{c}\text { K1. } \\
\text { pneumoniae }\end{array}$ \\
\hline Ampicillin & 10ug & $\mathrm{R}$ & $\mathrm{R}$ & ++ & $\mathrm{R}$ & $\mathrm{R}$ \\
\hline Amoxycillin & $25 \mathrm{ug}$ & $\mathrm{R}$ & $\mathrm{R}$ & $\mathrm{R}$ & $\mathrm{R}$ & $\mathrm{R}$ \\
\hline Enrofloxacin & $5 u g$ & +++ & +++ & +++ & +++ & +++ \\
\hline Erythromycin & $15 \mathrm{ug}$ & $\mathrm{R}$ & $\mathrm{R}$ & $\mathrm{R}$ & ++ & ++ \\
\hline Gentamycin & 10ug & +++ & +++ & +++ & +++ & +++ \\
\hline Streptomycin & 10ug & $\mathrm{R}$ & $\mathrm{R}$ & ++ & ++ & ++ \\
\hline Penicillin & 10ug & $\mathrm{R}$ & $\mathrm{R}$ & ++ & ++ & ++ \\
\hline Chloramphenicol & 130ug & +++ & +++ & ++ & ++ & ++ \\
\hline Oxytetracyclin & $30 u g$ & ++ & ++ & +++ & ++ & ++ \\
\hline $\begin{array}{r}\text { Trimethoprim-Sul } \\
\text { Methoxazol } 1 \\
\end{array}$ & $3.75 \mathrm{ug}$ & ++ & ++ & $\mathrm{R}$ & $\mathrm{R}$ & $\mathrm{R}$ \\
\hline
\end{tabular}

Highly sensitive $=+++\quad$ Moderately sensitive $=++\quad$ Resistance $=\mathrm{R}$

\section{DISCUSSION}

Diarrhoea is very common in the calf and can have an impact both economically and in terms of animal welfare. Looses are duo to death, treatment costs and time spent on care, as well as subsequent chronic illthrift and poor growth. It may be convenient to focus on the principal infectious causes of calf diarrhoea.

The bacteriological examination of 120 faecal samples from calves revealed $97(80.83 \%)$ positive bacterial infection, from which $67(69.1 \%)$ yielded a single pure isolate and 30(30.9\%) yielded a mixed bacterial isolates (Table 1). Mixed infection are frequently seen and clinical signs are usually more severe where more than one pathogen is involved (Bazeley, 2003). High percentage of mixed cultures were obtained from diarrhoeic calves (41.46 and 30.32\% for buffaloe acd cows calves respectively). The incidence of isolation of one organism from, diarrhoeic buffaloe, cows calves, apparently healthy buffaloe, cows calves were 58.54, 69.77 and $100 \%$ for each respectively.

Results in Table (2) revealed that isolated bacterial pathogens were E.coli 47(37\%), Pseudomonas aeruginosa 20(15.75\%). Campylobacter spp. 18(14.17\%), Salmonella spp. 14(11.03\%), Proteus vulgaris $12(9.45 \%)$ and $8(6.3 \%)$ each of Klebsiella pneumoniae and Staphylococcus aureus. Nearly similar pathogens were isolated by McDonough, et al., (1994); Asma, et al., (1996); Meltzer and Shpigel, (1996); Rajeswari and Shome, (1996); Sadiek and Schlerka, (1996); 
Zayed, (1998); Sadiek and Hussein, (1999); Samad, et al., (2004); Maarouf and Mobark, 2007).

E.coli is a gram-negative, lactose-fermenting, indole positive, facultative anaerobe of human and animal intestinal flora. In this study E.coli was the most prevalent isolates with an incidence of $37 \%$. All the isolated E.coli strains from diarrhoeic calves were enterotoxigenic produce heat labile enterotoxin (LT) When tested by VET-RPLA kits and serologically identified as $28 \%\left(\mathrm{O}_{119}\right) ; 20 \%\left(\mathrm{O}_{26}\right) ; 12 \%\left(\mathrm{O}_{55}\right)$; $8 \%\left(\mathrm{O}_{101}\right)$ and $32 \%$ untypable strains, Table (3). The association of these serotypes with buffaloe and cows diarrhoea were reported by Mona, 1995 and Harbby, 2002. This result go hand in hand with that reported by Abd-El-Galil, et al., (1983); Jayappa, et al., (1984) and Asma, et al., (1996) who recorded that E.coli is the main cause of diarrhoea affecting newly born calves.

Generally in E.coli infections, diarrhoea occurs through the effect of enterotoxins which stimulate adenyl cyclase activity of intestinal and capillary epithelium (heat labile toxin, LT), resulting in hypersecretion of electrolytes $\left(\mathrm{Na}^{+} \& \mathrm{HcO}_{3}\right)$ and an increased diffusion of water into lumen of the intestine (Kaske, 1993 and Muller, et al., 1996). Also LT have been shown as well to reduce the absorption of fluid and electrolytes from the intestinal lumen, (Sears and Kaper, 1996).

Salmonellosis is a very important disease not only from the economic point of view but also from the public health aspect as it is zoonotic disease, it occurs worlds wide and its incidence is on increase (Englar, 1988 and Corrier, et al., 1990). The results given in Tables $(2,3)$ revealed that Salmonella could be isolated from diarrhoeic calves with an incidence 14(11.03\%). This result was nearly similar with Novert and Hammad (2001) who found that $14.66 \%$ were positive for Salmonella, while it was higher than El-Hamamy, et al., (1999) who could isolate Salmonella from $5.0 \%$ of the examined samples and disagree with Asma, et al., (1996) who found that $27.7 \%$ were positive for Salmonella.

Salmonella spp. infection causes severe mucosal damage and increase permeability of the mucosal epithelium that result in uncontrolled lakage of water and ions into the intestinal lumen (Robinson and Huxtable, 1988). On serotyping of 14 recovered Salmonella organism from examined samples, 6(42.86\%) of which were recognized as Salmonella typhimurium; 6(42.86\%) were Salmonella enteritidis and 2(14.28\%) were untyped. Some authors recorded Salmonella typhimurium and Salmonella enteritidis from diarrhoeic 
calves, (McLaran and Nrag, 1991; Lance, et al., 1992; Asma, et al., 1996; El-Hamamy, et al., 1999; Sadiek and Hussein, 1999 and Novert and Hammad, 2001).

Campylobacters are an important cause of diarrhoeal disease throughout the world (Griffiths and Park, 1990). Also were resposible for the majority of diarrhoea (Gossens, et al., 1995). Bacteriological examination revealed that $18(14.17 \%)$ were positive for Campylobacters, this result disagree with Adesiyun, et al. (1992) and Novert and Hammad (2001) who found that $20.5 \%$ and $22.66 \%$ of the examined calves were positive for Campylobacters respectively. These variations could be attributed to the contamination level and method of isolation.

Klebsiella pneumoniae is a typical member of enterobacteriaceae that produce endotoxin following penteration through intestinal or respiratory mucosa. The results in Table (2) revealed that Klebsiella pneumoniae was isolated from $8(6.3 \%)$ of the examined samples. This result nearly similar with that reported by Al-Khayyat, et al. (1977) and Roushdy (1986).

Pseudomonas aeruginosa was recovered from 20(15.75\%) of diarrhoeic calves. With regard to Proteus vulgaris a total of 12 isolates could be isolated with a percentage of $9.45 \%$. Staphylococcus aureus could be isolated from $8(6.3 \%)$ of the examined samples. Similar recovered microorganisms were reported by Oliveir, et al. (1989) and Mannaa, et al. (1993).

Neonatal diarrhoea in calves is often treated with antimicrobial drug, however, antibiotic therapy is frequently ineffective, partly due to the presence of drug reistant strains and the failure to identify drug sensitivity (Orden, et al., 2000). In vitro sensitivity testing of isolates revealed that most isolates were highly sensitive to Enrofloxacin, Gentamycin and Chloramphenicol and resistance to Ampicillin and Amoxycillin (Table 4). Nearly similar results were reported by Mona, (1995); Asma, et al., (1996); Abd-El-Kadar, et al., (2002) ; Maarouf and Mobark (2007).

Finally we can conclud that cases of calves diarrhoea is sequel of infection with various intestinal pathogens which is exaggerated with stress factors such as improper feeding, unsanitary condition of drinking and bad hygienic surroundings. So attention must be paid for laboratory diagnosis of diseased calves and determining the pathogens present, is important as it does help to indicate possible lines of therapy, future control measures and show any potential zoonotic risks. 


\section{REFERENCES}

Abd El-Galil, Y.; El-Kabbany, A. and Kiroloss, F.N. (1983): Studies on diarrhoea in buffaloes calves: 1-Bacterial causes and their sensitivity to a new synthetic bactericide imequyl in comparison with some antibiotics in vitro. Proceedings of VII ${ }^{\text {th }}$ International Symp. of World Association of Vet. Microbiologists Immunologists and Specialists in Infectious Diseases, Barcelona, Spain (in press).

Abd El-Kader, H.A.; Bastaworos, A.F. and Seddek, S.R. (2002): Studis on role of enterobacteriaceae in newly born Friesian calves diarrhoea in Assiut and Quena Governorates with special reference to their sensitivity to some antibacterial agents. Assiut Vet. Med. J., 46 (92): 178-186.

Adesiyun, A.A.; Kaminjolo, J.S.; Loregnard, R. and Kitson-Piggott, W. (1992): Campylobacter infection in calves, piglets, lambs and kids in trinidad. Br. Vet. J., 148 (6): 547-556.

Al-Khayyat, A.; Abd-Allah, I.S.; Zafer, S.A.W. and Habasha, F.G. (1977): Severe outbreaks of calf scours in Baghdad Province. Egypt. Vet. Med. J., 25: 221-230.

Asma, O. Aly; Zamzam, H. Abd El-Wahed and El-Sheikh (1996): Some studies on clinical, haematological and biochemical in diarrhoeic neonatal buffalo calves with reference to hygienic conditions. Assiut Vet. Med. J. 35 (69): 91-104.

Bazeley, K. (2003): Investigation of diarrhoea in the neonatal calf. InPractice. 25 (3):152-159.'

Byomi, A.; Herbst, W. and Baljer, G. (1996): Some viral agents associated neonatal calf diarrhoea. Assiut Vet. Med. J., 35 (70): 96-104.

Collins, C.H.; Lyne, P.M. and Grange, J.M. (1995): Microbiological methods. $7^{\text {th }}$ Ed. Butterworth-Heinemann Ltd, Linacre House Jordan Hill Oxford, OX 28 DP.

Corrier, D.E.; Purdy, L.W. and Daloach, J.P. (1990): Effect of marketing stress on faecal excretion of Salmonella spp. in feeder calves. Am. J. Vet. Res., 51(6): 866-869.

Cruickshank, R.; Duguid, J.P.; Marmoni, B.P. and Swain, R.H. (1982): Medical Microbiology. $12^{\text {th }}$ Ed. Churonill Livingestone Edinburg, London, UK. 
Edwards, P.R. and Ewing, W.H. (1972): Identification of enterobacteriacae, Burgess Publ. Co. Minnecopolis Minnesota. P.103-104.

El-Hamamy, M.M.; El-boushy, M.E. and Fetaih, H.A. (1999): Some studies on newly born calves problems with relationship to their immune status .Suez Canal Vet. Med. J., 11 (2): 289-307.

Engler, K. (1988): Salmonellosis in laboratory animal. Animal Welfare Information Center.

Finegold, S.M. and Baron, E.J. (1986): Diagnosis Microbiology $7^{\text {th }}$ Ed. PP. 186. The C.V. Mosby Company. St. Louis. Toronto. Princention.

Gossens, H.; Giesendrof, B.A.J. and Vandamme, P. (1995): Investigation of an outbreak of Campylobacter upsaliensis in day car centers in Brusels: Analysis of relationships among isolates by phenotypic and genotypic typing methods. J. Infect. Dis., 172: 1298-1305.

Griffiths, P.L. and Park, R.W.A. (1990): Campylobacter associated with human diarrhoeal disease. J. Appl. Bacteriol., 69:281-301.

Harbby, H.A. (2002): Bacterial causes of diarrhea in small animals (kids, lambs and calves) in Sultanate of Oman. J. Egypt. Vet. Med. Ass., 62 (3): 227-235.

Jayappa, H.G.; Strayer, J.G. and Goodnow, R.A. (1984): Controlling Colibacillosis in neonatal calves. J. Vet. Med. Small Animal Clinic., 79 (3): 388-394.

Kaske, M. (1993): Physiologische Funktionen des Gastrointestinal trakts und pathophysiologische Veraenderungen bei der neonatalen Diarrhoe des Kalbes. Dtsch. Tieraeztl. Wschr. 100: 434-439.

Kaufmann, F. (1973): Serological diagnosis of Salmonella spp. Kaufmann-White Schem, Copenhagen, Denmark.

Koneman, E.W.; Allen, S.D.; Janda, W.M.; Sehrechenberger, P.C. and Winn, W.C. (1994): Introduction to Diagnostic Microbiology. J.B. Lippincott Company, Philadelpha.

Lance, S.E.; Miller, G.Y. and Hancock, D.D. (1992): Salmonella infection in neonatal dairy calves. Amer. Vet. Ass., 201(6): 864-866.

Maarouf, A.A. and Mobark, M.G. (2007): Some bacteriological and biochemical studies on calf diarrhoea and trials of treatment. $5^{\text {th }}$ Int. Sci. Conf. Mansoura., 577-594. 
Manaa, A.M.; Sayed, A.M.; Thabet, El-R.A. and Abd El-Fattah (1993): Some microbial and blood biochemical studies on buffalo calves suffering from enteritis. Assiut Vet. Med. J., 29 (58): 144-153.

McDonough, S.P.; Stull, C.C. and Osbon, B.J. (1994): Enteric pathogens in intensively reared veal calves. A.J.V.R., 55: 1516-1520.

McLaren, I.M. and Nrag, C. (1991): Epidemiology of Salmonella typhimurium infection in calves, persistence of Salmonella on calf units. Vet. Rec., 129 (2):461-462.

Meltzer, R. and Shpigel, N.Y. (1996): Etiologic and epidemiologic aspects of calf diarrhea in Israili dairy farms. BCVA Edinburgh, Vol.1: 93-97.

Mona, A.A. (1995): Studies on the bacterial causes of enteritis in buffalo calves in Ismailia Governorate. M.V.Sc. Thesis, Fac. Vet. Med. Zagazig Univ.

Muller, U.; Brandsch, M.; Prasad, P.D.; Fei, Y.J.; Ganapathy, V. and Leibach, F.H. (1996): Inhibition of the H+/peptide contran sporter in human intestinal cell line Caco-z by cyclic AMP .Biochem. Biophys. Res. Commun. 218: 461-465.

Novert, M.H. and Hammad, A.M. (2001): Studies on mycotic and bacterial enteritis in calves. J. Egypt. Vet. Med. Ass., 61 (6B): 191-201.

Oliveir, A.A.DE.; Pedreira, P.A.S. and Almeida, M.F. (1989): Diseases of calves: Bacterial diarrhoea in sergipe state, Brazil, Arquivo Brasileiro de Medicina Veterinaria. Ezootecina., (41) 3: 213-222.

Orden, J.A.; Rutz-Santa-Qutteria, J.A.; Garcia, S; Cid, D. and De La Fuente, R. (2000): In vitro susceptability of Escherchia coli strains isolated from diarrhoeic dairy calves to 15 antimicrobial agent. J. Vet. Med. B47: 329-335.

Oxoid Manual (1998): The Oxoid manual of culture media, ingredients and other laboratory services $8^{\text {th }}$ Ed. Oxoid Limit.

Prescott, J.F. and Munroe, D.L. (1982): Campylobacter jejuni in man and animal. J. Am. Vet. Med. Ass., 181(12): 1529-1542.

Quinn, P.J.; Markey, B.K.; Carter, M.E.; Donelly, W.J.C. and Leonard, F.C. (2002): Veterinary Microbiology and Microbial Disease. MPG Books Itd, Bodmin, Cornwall LI.K.

Quinn, P.J.; Carter, M.E.; Markey, B.K. and Carter, G.P. (1994): A Text Book of Clinical Microbiology. Wolfe Publising. Mosby, London, WCIE 7DP, England. 
Radostits, O.M; Blood, D.C and Gay, C.C. (1994): Veterinary Medicine, A text book for the diseases of cattle, sheep, pigs, goats and horses, $8^{\text {th }}$ Ed. Bailliere Tindall London Philadelphia, Sydeny Tokyo Toronto.

Rajeswari, S. and Shome, B.R. (1996): Bacteriological study on calf diarrhoea cases in Andamans. Ind. Vet. J. 73 (9): 1001-1002.

Robinsion, W.F. and Haxtable, C.R.R. (1988): Clinicopathologic principles of Veterinary Medicine. $1^{\text {st }}$ Ed. Great Britian, Cambridge Univ. Press.

Roushdy, F.El-S.M. (1986): Studies on enteritis in different ages in calve. M.V.Sc. Thesis, (Pathology) Fac. Vet. Med. Zagazig Univ.

Sadiek, A. and Hussein, S.Z. (1999): Acute enteritis in neonate Friesian calves in Sohag Governorate with special reference to etiology, clinicobiochemical aspects and therapy. Assiut Vet. Med. J., 42 (83): 200-215.

Sadiek, A. and Schlerka, G. (1996): Rehydration therapie beim Durchfall erkranten Milchalber Tierarztl. Umschau 51: 544-554.

Samad, M.A.; Hossain, K.M.M.; Islam, M.A. and Saha, S. (2004): Mixed infection with gasterointestinal parasite and bacteria associated with diarrhoea in calves. Bangladesh J. of Vet. Med., 2 (1): 49-54.

Scotland, S.M.; Flowman, R.H. and Row, B. (1989): Evalution of a reversed passive latex agglutination test for detection of Escherchia coli heat-labile toxin in culture supernatants. J. Clin. Microbiol., 27: 339-340.

Sears, C.L. and Kaper, J.B. (1996): Enteric bacterial toxins: mechanisms of action and linkage to intestinal secretion. Microbiol. Rev., 60: 167-215.

Skirrow, M.B. and Benjamin, J. (1980): Campylobacter: Cultural characteristics of intestinal Campylobacters from man and animals. J. Hyg. Camb.85: 427-442.

Zayed, M.A. (1998): Comparative studies on the clinicopathological changs in calves suffering from enteritis induced by various agents. Ph.D. Thesis, Fac. Vet. Med. Zagazig Univ. 